\title{
ARAHAN PENGENDALIAN PERUBAHAN PENGGUNAAN LAHAN MENGGUNAKAN MARKOV - CELLULAR AUTOMATA DI KABUPATEN CIANJUR
}

\author{
Controlling Policy Of Land Use Change Using Markov-Cellular \\ Automata In Cianjur Regency
}

\author{
Rani Yudarwati ${ }^{1}$, Santun R.P Sitorus ${ }^{2}$, Khursatul Munibah' ${ }^{2}$
}

\begin{abstract}
Abstrak : Pengendalian laju perubahan penggunaan lahan sangat diperlukan agar keberlanjutan lingkungan dapat tetap terjaga. Salah satu upaya untuk menjaga keberlanjutan tersebut adalah dengan mempelajari perubahan yang terjadi beberapa tahun sebelumnya. Perubahan ini dapat dipelajari dengan pendekatan model Markov - Cellular Automata. Kabupaten Cianjur merupakan salah satu kabupaten yang rawan terhadap bencana longsor, sehingga perlu dilakukan pengendalian perubahan penggunaan lahan agar dapat terwujudnya keberlanjutan lingkungan yang sesuai dengan arahan tata ruang yang telah ditetapkan. Tujuan penelitian ini adalah mengetahui perubahan penggunaan lahan yang terjadi dan mengevaluasi penggunaan lahan tersebut terhadap RTRW serta menyusun arahan pengendalian perubahan penggunaan lahan. Hasil analisis menunjukkan Kabupaten Cianjur mengalami penurunan luasan hutan yang cukup besar yaitu sebesar 10,3\% dan ketidaksesuaian penggunaan lahan dengan RTRW sebesar 10,4\%. Hasil prediksi memperlihatkan bahwa perubahan tanpa ada skenario menyebabkan persentase ketidaksesuaian penggunaan lahan meningkat drastis menjadi $20,5 \%$. Skenario dimana dilakukan pengembalian fungsi hutan dapat menekan persentase ketidaksesuaian menjadi $16,6 \%$.
\end{abstract}

\section{Kata Kunci: Pengendalian, Perubahan Penggunaan Lahan, Markov - Cellular Automata}

\begin{abstract}
Controlling the rate of land use change is necessary due to maintaining environment sustainability. One of the efforts is studying the changes that occur in the past few years. These changes can be studied by Markov - Cellular Automata model. Cianjur is one of the regency that has a high risk of landslide hazard, so it is necessary to control land use change in order to realize environmental sustainability in accordance with the spatial plan of Cianjur regency (RTRW). The purpose of this study was to see land use changes that occurred and evaluated with the spatial plan (RTRW) and also to conduct controlling scenarios of land use changes. The analysis showed that Cianjur regency has drastically decreased in forest area up to $10,3 \%$ and landuse inconsistency of $10,4 \%$. The prediction results showed that landuse change without intervention would dramatically increase inconsistency up to $20,5 \%$. Land use scenario of restoring forest could reduce inconsistency up to $16,6 \%$.
\end{abstract}

Keywords : Controlling policy, Land use change, Markov - Cellular Automata

\footnotetext{
${ }^{1}$ Program Studi Ilmu Perencanaan Wilayah, Sekolah Pascasarjana, Institut Pertanian Bogor

2 Departemen Ilmu Tanah dan Sumberdaya Lahan, Fakultas Pertanian, Institut Pertanian Bogor
} 


\section{PENDAHULUAN}

Pola perubahan penggunaan lahan cenderung dinamis dan memiliki kecepatan perubahan yang berbeda di setiap wilayah. Hal ini dikarenakan perubahan yang terjadi sangat tergantung pada faktor pendorongnya. Faktor tersebut dominan terbagi dalam dua kategori, yaitu kondisi bio-fisik dan kondisi sosial-ekonomi. Faktor bio-fisik tidak mempengaruhi secara langsung, kebanyakan hanya menyebabkan terjadinya perubahan pada tutupan lahan atau mempengaruhi keputusan pengelolaan terhadap lahan tersebut yang merupakan aktivitas manusia. Seiring dengan semakin meningkatnya aktivitas manusia diberbagai sektor terutama sektor ekonomi, maka kebutuhan/permintaan akan sumberdaya lahan juga akan meningkat. Ketersediaan lahan yang relatif tetap akan menyebabkan tingginya kompetisi penggunaan lahan, namun pada akhirnya prioritas perubahan penggunaan lahan akan dimenangkan oleh desakan kebutuhan ekonomi dan sosial. Akibat dari desakan yang sangat kuat, diperlukan pengedalian laju perubahan penggunaan lahan agar keberlanjutan lingkungan dapat tetap terjaga. Salah satu upaya untuk menjaga keberlanjutan lingkungan adalah dengan mempelajari perubahan penggunaan lahan yang terjadi. McConnel (2006) menjelaskan bahwa studi perubahan penggunaan lahan tidak hanya mengalokasikan sejumlah penggunaan lahan tapi juga mempelajari variasi pola penggunaan lahan tersebut, sehingga ada proses monitoring terhadap penggunaan lahan. Terdapat banyak cara dalam mempelajari perubahan penggunaan lahan, seperti Markov - Cellular Automata.

Konsep Cellular Automata (CA) pada mulanya diperkenalkan oleh Ulam dan Neumann sekitar tahun 1940-an untuk menyediakan kerangka untuk menginvestigasi perilaku sistem yang kompleks (Huan et al, 2010). Metode ini merupakan sistem dinamis yang beroperasi dengan ruang dalam data raster dimana nilai data raster tersebut dapat didefinisikan kedalam data binari atau diskrit dan perilakunya dipengaruhi oleh ketetanggaan. Model Markov-CA merepresentasikan penggunaan lahan yang mana perubahannya tergantung pada aturan mempertimbangkan penggunaan lahan tetangganya (Manson, 2005). Chen et al. (2002) menjelaskan komponen utama Markov-CA adalah cell (piksel), state, neigborhood (ketetanggaan) dan transition function atau transition rule (fungsi perubahan). Cell atau piksel merupakan ruang dua dimensi yang berukuran sama dan berfungsi sebagai unit analisis dengan ukuran yang bervariasi. State adalah variabel diskrit pada setiap sel yang merupakan fungsi waktu (CSIRO, 2003). Perubahan penggunaan lahan pada setiap piksel tergantung pada penggunaan lahan periode sebelumnya dan penggunaan lahan tetangganya (Berger et al, 2001), serta dikontrol oleh satu sistem set aturan atau fungsi transisi.

Kabupaten Cianjur merupakan salah satu kabupaten di Jawa Barat yang rawan terhadap bencana longsor, karena topografi wilayahnya yang didominasi perbukitan. Sepanjang tahun 2011 hingga 2015, telah terjadi 54 kejadian bencana longsor yang tersebar di beberapa kecamatan (BPBD, 2015). Hal ini merupakan salah satu dampak dari kehilangan hutan yang marak terjadi. Berdasarkan penelitian Forest Watch Indonesia, selama rentang tahun 2000 hingga tahun 2009, Kabupaten Cianjur mengalami kehilangan luasan hutan terbesar yaitu sebesar $17,9 \%$ dari luas wilayahnya. Oleh karena itu, perlu dilakukan pengendalian perubahan penggunaan lahan agar dapat terwujudnya keberlanjutan lingkungan yang sesuai dengan arahan tata ruang yang telah ditetapkan.

\section{METODE PENELITIAN}

Penelitian dilaksanakan di Kabupaten Cianjur yang secara geografis terletak antara $6^{\circ}$ 21' - 7॰ 32' LS dan 106 42' - 107॰ 25’ BT dengan luas sebesar 359.469 ha (Gambar 1). 


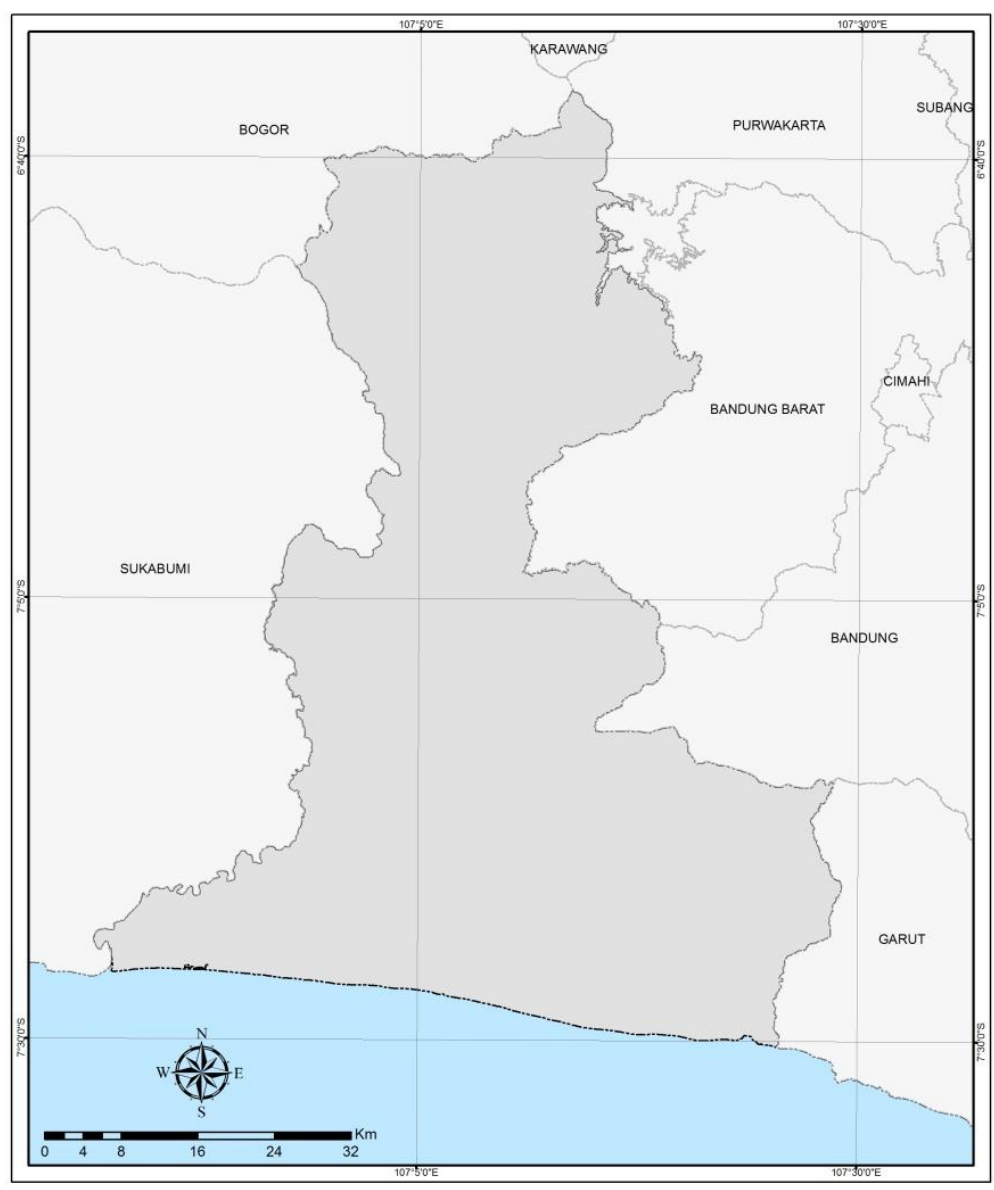

\section{Gambar 1 Peta Lokasi Penelitian}

Penelitian dilakukan untuk memprediksi perubahan penggunaan lahan dengan pendekatan model spasial dinamik. Tujuan penelitian ini adalah mengetahui perubahan penggunaan lahan yang terjadi dan mengevaluasi penggunaan lahan tersebut terhadap RTRW serta menyusun arahan pengendalian perubahan penggunaan lahan. Keterkaitan antara tujuan penelitian, data, metode analisis, dan hasil yang diharapkan secara ringkas disajikan pada Tabel 1.

Tabel 1 Matriks Hubungan antara Tujuan, Jenis Data, Metode dan Hasil

\begin{tabular}{|c|c|c|c|c|}
\hline No & Tujuan & Jenis Data & Metode & Hasil \\
\hline 1 & $\begin{array}{l}\text { Mengetahui } \quad \text { perubahan } \\
\text { penggunaan lahan yang terjadi }\end{array}$ & $\begin{array}{l}\text { Peta penggunaan lahan } \\
\text { tahun 2000, 2007, dan } \\
2014\end{array}$ & $\begin{array}{l}\text { Markov } \\
\text { Cellular } \\
\text { Automata }\end{array}$ & $\begin{array}{l}\text { Peta prediksi } \\
\text { penggunaan lahan }\end{array}$ \\
\hline 2 & $\begin{array}{l}\text { Mengevaluasi penggunaan } \\
\text { lahan terhadap RTRW }\end{array}$ & $\begin{array}{l}\text { Peta penggunaan } \\
\text { lahan eksisting } \\
\text { Peta penggunaan } \\
\text { lahan prediksi } \\
\text { Peta RTRW }\end{array}$ & $\begin{array}{l}\text { Overlay } \\
\text { Analisis } \\
\text { deskriptif }\end{array}$ & $\begin{array}{l}\text { Kesesuaian } \\
\text { penggunaan lahan } \\
\text { dengan RTRW }\end{array}$ \\
\hline 3 & $\begin{array}{l}\text { Menyusun arahan } \\
\text { Pengendalian perubahan } \\
\text { penggunaan lahan }\end{array}$ & $\begin{array}{l}\text { Peta penggunaan } \\
\text { lahan } \\
\text { Peta RTRW }\end{array}$ & $\begin{array}{l}\text { Cellular } \\
\text { Automata } \\
\text { Overlay } \\
\text { Analisis } \\
\text { deskriptif }\end{array}$ & $\begin{array}{l}\text { Skenario dan } \\
\text { arahan } \\
\text { pengendalian } \\
\text { lahan yang sesuai } \\
\text { dengan RTRW }\end{array}$ \\
\hline
\end{tabular}


Teknik analisis data yang digunakan untuk menjawab tujuan adalah sebagai berikut:

\section{Markov - Cellular Automata}

Pemodelan prediksi penggunaan lahan dilakukan dengan pendekatan metode Markov Chain dan Cellular Automata (CA). El-Hallaq dan Habboub (2015) menjelaskan proses Markov sebagai keadaan sistem pada waktu kedua dapat diprediksi dengan keadaan sistem pada waktu pertama dengan memberikan matriks probabilitas transisi dari masingmasing kelas penutupan lahan untuk setiap kelas penutupan lahan lainnya. Model MarkovCA menggunakan filter matriks berukuran 5 x 5 yang merupakan penerjemahan dari konsep ketetanggaan. Ukuran ini diartikan bahwa perubahan penggunaan lahan pada piksel pusat dipengaruhi oleh nilai 24 piksel tetangganya. Filter matriks ini sifatnya bergerak secara horizontal atau vertikal dalam melakukan analisis ketetanggaan pada suatu peta raster. Dalam melakukan simulasi perubahan penggunaan lahan, pada penelitian ini dilakukan prediksi perubahan tahun 2014 sebagai proses validasi model berdasarkan data penggunaan lahan tahun 2000 dan 2007. Kemudian baru dilakukan prediksi penggunaan lahan tahun 2025 dengan penambahan beberapa skenario pengendalian perubahan penggunaan lahan. Penyusunan skenario pengendalian perubahan penggunaan lahan dilakukan dengan melihat hasil perubahan penggunaan lahan yang terjadi dan terprediksi serta menentukan beberapa asumsi dalam pengendaliannya. Asumsi tersebut akan dimasukkan sebagai pembatas/skenario dalam proses prediksi sehingga dihasilkan perubahan penggunaan lahan yang diharapkan.

\section{Evaluasi Penggunaan Lahan terhadap RTRW}

Evaluasi penggunaan lahan dengan rencana tata ruang wilayah dilakukan pada dua titik tahun penggunaan lahan yang berbeda, yaitu pada penggunaan lahan aktual tahun 2014 dengan penggunaan lahan hasil prediksi tahun 2025. Evaluasi dilakukan menggunakan proses analisis tumpang susun (overlay). Hasil analisis memperlihatkan penggunaan lahan yang sudah sesuai dengan rencana tata ruang wilayah, tidak sesuai dengan rencana tata ruang wilayah serta lahan yang masih memungkinkan untuk berubah fungsi di masa yang akan datang.

\section{Arahan Pengendalian Perubahan Penggunaan Lahan}

Arahan pengendalian perubahan penggunaan lahan dihasilkan dengan memilih skenario prediksi penggunaan lahan yang memiliki nilai kesesuaian terbaik antara penggunaan lahan hasil prediksi dengan RTRW. Parameter yang digunakan sebagai arahan penggunaan lahan adalah skenario yang memiliki nilai sesuai terbesar dan ketidaksesuaian terkecil.

\section{HASIL DAN PEMBAHASAN}

\section{Analisis Perubahan Penggunaan Lahan}

Gambar 2 dan Gambar 3 menunjukkan penggunaan lahan di Kabupaten Cianjur berdasarkan hasil interpretasi tahun 2000, 2007, dan 2014. Penggunaan lahan yang mendominasi adalah hutan, lahan kering, dan sawah. Pada periode tahun 2000 hingga 2014, tren penggunaan lahan hutan di Kabupaten Cianjur terus menurun hingga mencapai $10,3 \%$. Penurunan luas hutan mengindikasikan adanya kerusakan lahan hutan terutama hutan pada kawasan lindung, yaitu : hutan lindung dan hutan konservasi. Hutan memiliki fungsi yang sangat penting dalam menjaga kelestarian lingkungan. 


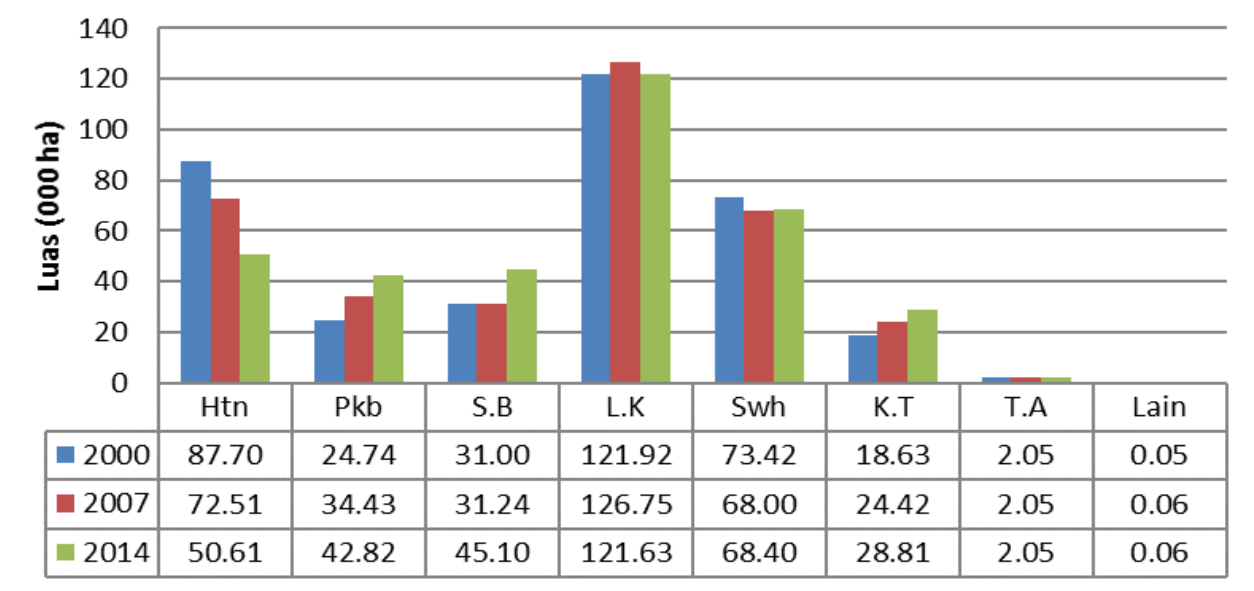

Gambar 2 Grafik Perubahan Penggunaan Lahan Kabupaten Cianjur

Perkebunan memberikan nilai ekonomi yang lebih tinggi dibandingkan lahan pertanian lainnya seperti sawah atau lahan kering terhadap ekonomi masyarakat sekitar, sedangkan semak belukar dan lahan kering sering diartikan sebagai wilayah transisi sebelum dimanfaatkan oleh masyarakat yang tinggal disekitarnya sehingga mempunyai nilai ekonomi. Namun, berbeda dengan lahan kering, semak belukar pada umumnya merupakan transisi dari penggunaan lahan hutan yang akan dijadikan penggunaan lain yang non-hutan. Semakin banyak semak belukar dan lahan kering yang terindentifikasi maka peluang lahan tersebut akan terkonversi akan semakin besar. Hal ini terlihat dari peningkatan luasan perkebunan dan semak belukar yang cukup signifikan yaitu sebesar $5 \%$ dan 3,9\% serta penurunan luasan lahan kering sebesar 0,2\%. Hal ini dikarenakan kondisi fisik wilayah Kabupaten Cianjur yang dominan berbukit membuat masyarakat lebih mudah memanfaatkan lahan menjadi pertanian lahan kering dibandingkan sawah.

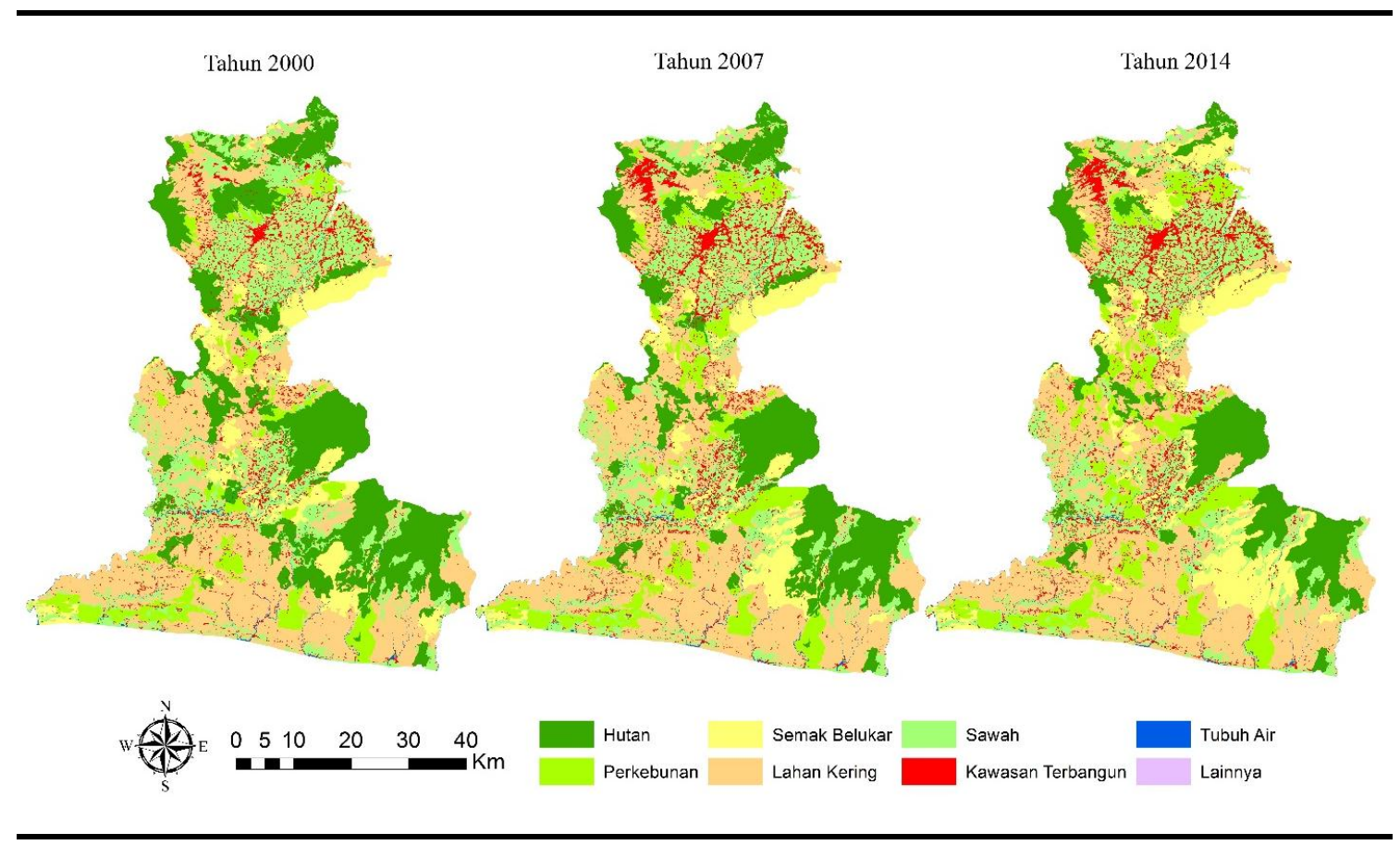

Gambar 3 Perubahan Penggunaan Lahan Kabupaten CianjurTahun 2000, 2007 dan 2014 
Penggunaan lahan sawah juga memiliki luasan yang relatif stabil. Saat ini dengan adanya Peraturan Pemerintah No 41 Tahun 2009 mengenai perlindungan lahan pertanian pangan berkelanjutan, pemerintah daerah berupaya menjaga wilayah sawahnya agar tidak berubah fungsi. Jika perubahan itu terjadi, hanya bersifat dari penggunaan lahan basah menjadi penggunaan lahan kering, dikarenakan pergantian musim dari musim hujan ke musim kemarau. Perubahan ini banyak terjadi pada sawah tadah hujan menjadi tegalan/tanaman semusim yang tidak memerlukan banyak air.

Kawasan terbangun di Kabupaten Cianjur mengalami peningkatan sebesar 2,8\%. Perubahan penggunaan lahan menjadi kawasan terbangun dominan terjadi di bagian utara. Hal ini dikarenakan di bagian Utara Cianjur terdapat kawasan wisata Puncak yang menjadi destinasi baik wisatawan lokal dan mancanegara. Kawasan Puncak saat ini juga menjadi bagian dari Kawasan Strategis Nasional (KSN) yang diharapkan dapat menjaga kelestarian lingkungan sehingga dapat melindungi wilayah yang berada dibawahnya. Namun faktanya adalah pembangunan kawasan terbangun seperti rumah perisitirahatan atau vila semakin marak terjadi.

Tabel 2 menunjukkan nilai kesesuaian penggunaan lahan eksisting dengan RTRW. Berdasarkan hasil perbandingan, didapatkan bahwa penggunaan lahan eksisting Kabupaten Cianjur memiliki kesesuaian penggunaan lahan dengan RTRW sebesar 40,8\%, tidak sesuai sebesar 10,4\% dan penggunaan lahan yang memungkinkan untuk berubah 48,8\%. Penyebab ketidaksesuaian dominan terjadi pada lahan kering dan semak belukar yang berada di Kawasan Lindung. Hal ini nyata menunjukkan perambahan hutan marak terjadi.

Tabel 2 Evaluasi Penggunaan Lahan Kabupaten Cianjur Tahun 2014 dengan RTRW

\begin{tabular}{lllllllll}
\hline & \multicolumn{6}{c}{ Rencana Tata Ruang Wilayah Kabupaten Cianjur (dalam 000 ha) } \\
\cline { 2 - 8 } $\begin{array}{l}\text { Pernggunaan } \\
\text { Lahan }\end{array}$ & Kws & Kws & Kws & Kws & Kws & Kws & Tubuh & Jumlah \\
& Lindung & $\begin{array}{l}\text { Hutan } \\
\text { Produksi }\end{array}$ & Perkebunan & PLK & PLB & Terbangun & Air & \\
\hline Hutan & $36,4 \mathrm{a})$ & $9,3 \mathrm{~b})$ & $3,8 \mathrm{~b})$ & $1,0 \mathrm{~b})$ & $0,2 \mathrm{~b})$ & $0,0 \mathrm{~b})$ & $0,0 \mathrm{~b})$ & 50,6 \\
Perkebunan & $2,7 \mathrm{c})$ & $15,1 \mathrm{~b})$ & $19,8 \mathrm{a})$ & $4,8 \mathrm{~b})$ & $0,2 \mathrm{~b})$ & $0,2 \mathrm{~b})$ & $0,0 \mathrm{~b})$ & 42,8 \\
Semak Belukar & $8,4 \mathrm{c})$ & $12,4 \mathrm{~b})$ & $15,9 \mathrm{~b})$ & $7,5 \mathrm{~b})$ & $0,5 \mathrm{~b})$ & $0,1 \mathrm{~b})$ & $0,2 \mathrm{~b})$ & 45,1 \\
Lahan Kering & $12,0 \mathrm{c})$ & $10,9 \mathrm{~b})$ & $45,6 \mathrm{~b})$ & $48,8 \mathrm{a})$ & $3,3 \mathrm{~b})$ & $1,0 \mathrm{~b})$ & $0,0 \mathrm{~b})$ & 121,6 \\
Sawah & $6,9 \mathrm{c})$ & $2,0 \mathrm{~b})$ & $9,5 \mathrm{~b})$ & $27,7 \mathrm{~b})$ & $18,1 \mathrm{a})$ & $4,1 \mathrm{~b})$ & $0,1 \mathrm{~b})$ & 68,4 \\
K. Terbangun & $0,7 \mathrm{c})$ & $0,2 \mathrm{c})$ & $1,7 \mathrm{c})$ & $2,6 \mathrm{c})$ & $2,0 \mathrm{c})$ & $21,5 \mathrm{a})$ & $0,0 \mathrm{c})$ & 28,8 \\
Tubuh Air & $1,8 \mathrm{a})$ & $0,0 \mathrm{c})$ & $0,0 \mathrm{c})$ & $0,1 \mathrm{c})$ & $0,0 \mathrm{c})$ & $0,0 \mathrm{c})$ & $0,1 \mathrm{a})$ & 2,0 \\
Lainnya & $0,0 \mathrm{~b})$ & $0,0 \mathrm{~b})$ & $0,0 \mathrm{~b})$ & $0,0 \mathrm{~b})$ & $0,0 \mathrm{~b})$ & $0,0 \mathrm{~b})$ & $0,0 \mathrm{~b})$ & 0,1 \\
\hline Jumlah & 68,9 & 49,9 & 96,4 & 92,6 & 24,3 & 27,0 & 0,4 & 359,5 \\
\hline
\end{tabular}

Keterangan : a) sesuai dengan RTRW, b) masih dapat berubah fungsi, c) tidak sesuai dengan RTRW

\section{Prediksi Penggunaan Lahan Tahun 2025}

Prediksi perubahan penggunaan lahan ditujukan untuk mengestimasi perubahan penggunaan lahan pada tahun 2025. Penentuan prediksi dilakukan dengan menjadikan peta penggunaan lahan tahun 2000 sebagai tahun dasar dan tahun 2014 sebagai tahun kedua dalam analisis Markov Chain., kemudian tahun 2014 sebagai tahun dasar pada analisis Cellular Automata dengan jumlah iterasi sebanyak 11 kali. Tabel 3 memperlihatkan hasil prediksi penggunaan lahan tahun 2025 di Kabupaten Cianjur. Pada tahun 2025 diprediksi akan mengalami penurunan luas pada penggunaan lahan hutan sebesar 6,4\% serta lahan kering dan sawah masing-masing sebesar 2,9\% dan 2,8\%. Peningkatan luas terbesar terjadi pada penggunaan lahan kawasan terbangun sebesar 6,3\% kemudian perkebunan sebesar $4,9 \%$ dan semak belukar sebesar $0,9 \%$. 
Tabel 3 Prediksi Luas dan Perubahan Penggunaan Lahan di Kabupaten Cianjur

\begin{tabular}{llllclcr}
\hline \multirow{2}{*}{ Penggunaan Lahan } & \multicolumn{5}{c}{ Kabupaten Cianjur } \\
\cline { 2 - 7 } & \multicolumn{2}{c}{ 000 ha } & \multicolumn{2}{c}{2014} & 000 ha & $\%$ & Perubahan \\
\cline { 2 - 7 } Hutan & 50,6 & 14,1 & 27,8 & 7,7 & $-22,8$ & $-6,4$ \\
Perkebunan & 42,8 & 11,9 & 60,4 & 16,8 & 17,6 & 4,9 \\
Semak Belukar & 45,1 & 12,5 & 48,3 & 13,4 & 3,2 & 0,9 \\
Lahan Kering & 121,6 & 33,8 & 110,9 & 30,8 & $-10,7$ & $-2,9$ \\
Sawah & 68,4 & 19,0 & 58,3 & 16,2 & $-10,1$ & $-2,8$ \\
K. Terbangun & 28,8 & 8,0 & 51,4 & 14,3 & 22,6 & 6,3 \\
Tubuh Air & 2,0 & 0,6 & 2,3 & 0,6 & 0,2 & 0 \\
Lainnya & 0,1 & 0 & 0,2 & 0 & 0,1 & 0 \\
\hline Jumlah & 359,5 & 100 & 359,5 & 100 & 0 & 0 \\
\hline
\end{tabular}

Tabel 4 menunjukkan nilai kesesuaian penggunaan lahan prediksi dengan RTRW. Berdasarkan hasil perbandingan didapatkan bahwa penggunaan lahan prediksi di Kabupaten Cianjur memiliki kesesuaian penggunaan lahan prediksi dengan RTRW sebesar $36,3 \%$, tidak sesuai meningkat tajam menjadi sebesar $20,5 \%$ dan penggunaan lahan yang memungkinkan untuk berubah $43,2 \%$.

Tabel 4 Evaluasi Penggunaan Lahan Prediksi Kabupaten Cianjur dengan RTRW

\begin{tabular}{|c|c|c|c|c|c|c|c|c|}
\hline \multirow{3}{*}{$\begin{array}{l}\text { Penggunaan } \\
\text { Lahan }\end{array}$} & \multicolumn{8}{|c|}{ Rencana Tata Ruang Wilayah Kabupaten Cianjur (dalam 000 ha) } \\
\hline & Kws & Kws & Kws & Kws & Kws & Kws & Tubuh & \multirow[t]{2}{*}{ Jumlah } \\
\hline & Lindung & $\begin{array}{l}\text { Hutan } \\
\text { Produksi }\end{array}$ & Perkebunan & PLK & PLB & Terbangun & Air & \\
\hline Hutan & $21,0 \mathrm{a})$ & $4,0 \mathrm{~b})$ & $1,9 b)$ & $0,6 \mathrm{~b})$ & $0,1 \mathrm{~b})$ & $0,1 \mathrm{~b})$ & $0,0 \mathrm{~b})$ & 27,8 \\
\hline Perkebunan & $8,4 c)$ & $20,2 b)$ & $24,4 a)$ & $6,6 \mathrm{~b})$ & $0,5 b)$ & $0,2 b)$ & $0,0 \mathrm{~b})$ & 60,4 \\
\hline Semak Belukar & $16,2 \mathrm{c})$ & $12,4 b)$ & $12,3 b)$ & $6,1 b)$ & $0,5 b)$ & $0,6 b)$ & $0,2 b)$ & 48,3 \\
\hline Lahan Kering & $12,9 c)$ & $10,7 b)$ & $39,9 b)$ & $45,8 a)$ & $0,8 b)$ & $0,7 b)$ & $0,0 \mathrm{~b})$ & 110,9 \\
\hline Sawah & $7,0 c)$ & $1,6 b)$ & $8,1 b)$ & $24,2 b)$ & $14,5 \mathrm{a})$ & $2,8 b)$ & $0,1 \mathrm{~b})$ & 58,3 \\
\hline K. Terbangun & $0,8 c)$ & $0,8 c)$ & $9,8 c)$ & $9,6 c)$ & $7,9 c)$ & $22,6 a)$ & $0,0 c)$ & 51,4 \\
\hline Tubuh Air & $1,8 \mathrm{a})$ & $0,0 c)$ & $0,1 c)$ & $0,1 \mathrm{c})$ & $0,0 \mathrm{c})$ & $0,1 c)$ & $0,1 \mathrm{a})$ & 2,3 \\
\hline Lainnya & $0,0 c)$ & $0,0 \mathrm{~b})$ & $0,0 \mathrm{~b})$ & $0,0 \mathrm{~b})$ & $0,0 \mathrm{~b})$ & $0,1 \mathrm{~b})$ & $0,0 \mathrm{~b})$ & 0,2 \\
\hline \multirow{2}{*}{ Jumlah } & 6 & 49 & \multirow{2}{*}{96,4} & & & \multirow{2}{*}{27,1} & \multicolumn{2}{|c|}{0} \\
\hline & 8,3 & ,9 & & 3,0 & 4,3 & & ,4 & 59,5 \\
\hline
\end{tabular}

Keterangan : a) sesuai dengan $R T R W, b)$ masih dapat berubah fungsi, c) tidak sesuai dengan RTRW

Berdasarkan hasil prediksi, peningkatan kawasan terbangun dan semak belukar selalu diikuti oleh penurunan hutan. Jika hal ini terus dibiarkan tanpa kendali akan membahayakan kondisi lingkungan di Kabupaten Cianjur dan resiko bencana longsor pun juga semakin tinggi.

\section{Arahan Pengendalian Perubahan Penggunaan Lahan}

Perubahan penggunaan lahan yang terjadi saat ini menunjukkan adanya dinamika pada setiap kelas penggunaan lahan. Jika dilihat dari perubahan yang terjadi saat ini serta gambaran hasil prediksi mengindikasikan bahwa perlu dilakukan pengendalian sehingga dapat meminimalkan kemungkinan terburuk yaitu bencana longsor. Salah satu cara yang bisa dilakukan agar perubahan penggunaan lahan dapat terkendali adalah dengan menyusun beberapa skenario dibuat dengan tujuan untuk meningkatkan kembali luasan 
penggunaan lahan hutan dan menurunkan ketidaksesuaian penggunaan lahan yang akan datang dengan RTRW masing-masing kabupaten. Skenario ini menggunakan asumsi bahwa terdapat intevensi pemerintah daerah dalam perubahan penggunaan lahan yang akan terjadi. Beberapa hal yang dimiliki oleh pemerintah melalui skenario ini yaitu terdapat anggaran yang cukup, terdapat jumlah personel yang cukup dan adanya penegakan hukum yang konsisten terhadap pelanggaran yang terjadi. Skenario dibuat menggunakan kebijakan spasial dan pembatasan area yang kemudian dimasukkan sebagai input untuk simulasi prediksi penggunaan lahan. Terdapat tiga skenario untuk mengendalikan perubahan penggunaan lahan di Kabupaten Cianjur. Skenario pertama dibuat kebijakan yang bersifat optimis yaitu penggunaan lahan hutan yang spesifik berada di kawasan lindung di pertahankan atau tidak boleh ada perubahan fungsi. Luas penggunaan lahan hasil prediksi dengan skenario ini ditampilkan pada Tabel 5 dan sebaran spasial ditampilkan pada Gambar 4.

Tabel 5 Luas dan Perubahan Penggunaan Lahan Kabupaten Cianjur Skenario 1

\begin{tabular}{lcrrrrr}
\hline \multirow{2}{*}{ Penggunaan Lahan } & \multicolumn{7}{c}{ Kabupaten Cianjur } \\
\cline { 2 - 7 } & \multicolumn{2}{c}{2014} & \multicolumn{2}{c}{2025} & \multicolumn{2}{c}{ Perubahan } \\
\cline { 2 - 7 } & 000 ha & 000 ha & $\%$ & 000 ha & $\%$ \\
\hline Hutan & 50,6 & 14,1 & 28,3 & 7,9 & $-22,3$ & $-6,2$ \\
Perkebunan & 42,8 & 11,9 & 60,4 & 16,8 & 17,6 & 4,9 \\
Semak Belukar & 45,1 & 12,5 & 48,3 & 13,4 & 3,2 & 0,8 \\
Lahan Kering & 121,6 & 33,8 & 110,9 & 30,8 & $-10,7$ & $-2,9$ \\
Sawah & 68,4 & 19,0 & 58,3 & 16,2 & $-10,1$ & $-2,8$ \\
K. Terbangun & 28,8 & 8,0 & 50,9 & 14,2 & 22,1 & 6,2 \\
Tubuh Air & 2,0 & 0,6 & 2,3 & 0,6 & 0,2 & 0 \\
Lainnya & 0,1 & 0 & 0,2 & 0 & 0,1 & 0 \\
\hline Jumlah & 359,5 & 100 & 359,5 & 100 & 0 & 0 \\
\hline
\end{tabular}

Hasil prediksi skenario 1 menunjukkan terdapat peningkatan persentase kawasan terbangun sebesar $6,2 \%$ dan semak belukar sebesar $0,8 \%$. Wilayah yang berubah menjadi kawasan terbangun masih dominan berada di bagian utara yang berbatasan langsung dengan Kabupaten Bogor. Penggunaan lahan hutan mengalami penurunan yaitu sekitar $6,2 \%$. Perubahan ini tidak terlalu jauh berbeda dengan penggunaan lahan hasil prediksi tanpa adanya skenario. Sawah dan lahan kering juga mengalami penurunan masing-masing sebesar 2,9\% dan 2,8\%. Hasil evaluasi kesesuaian dengan RTRW menunjukkan Kabupaten Cianjur memiliki kesesuaian penggunaan lahan prediksi dengan RTRW sebesar 36,6\%, tidak sesuai sebesar $20,4 \%$ dan penggunaan lahan yang memungkinkan untuk berubah $43,0 \%$.

Skenario 2 dengan kebijakan yang bersifat moderat dimana hutan dan semak belukar yang berada di kawasan lindung di pertahankan atau tidak boleh ada perubahan fungsi. Luas penggunaan lahan hasil prediksi dengan skenario ini ditampilkan pada Tabel 6.

Tabel 6 Luas dan Perubahan Penggunaan Lahan Kabupaten Cianjur Skenario 2

\begin{tabular}{llcccccc}
\hline & \multicolumn{5}{c}{ Kabupaten Cianjur } \\
\cline { 2 - 7 } Penggunaan Lahan & \multicolumn{2}{c}{2014} & \multicolumn{2}{c}{2025} & \multicolumn{2}{c}{ Perubahan } \\
\cline { 2 - 8 } & \multicolumn{2}{c}{000 ha } & & 000 ha & $\%$ & 000 ha & $\%$ \\
\hline Hutan & 50,6 & 14,1 & 42,5 & 11,8 & $-8,1$ & $-2,3$ \\
Perkebunan & 42,8 & 11,9 & 60,4 & 16,8 & 17,6 & 4,9 \\
Semak Belukar & 45,1 & 12,5 & 33,7 & 9,4 & $-11,4$ & $-3,2$
\end{tabular}




\begin{tabular}{|c|c|c|c|c|c|c|}
\hline \multirow{3}{*}{ Penggunaan Lahan } & \multicolumn{6}{|c|}{ Kabupaten Cianjur } \\
\hline & \multicolumn{2}{|c|}{2014} & \multicolumn{2}{|c|}{2025} & \multicolumn{2}{|c|}{ Perubahan } \\
\hline & 000 ha & $\%$ & 000 ha & $\%$ & 000 ha & $\%$ \\
\hline Lahan Kering & 121,6 & 33,8 & 114,1 & 31,7 & $-7,5$ & $-2,1$ \\
\hline Sawah & 68,4 & 19,0 & 54,5 & 15,1 & $-13,9$ & $-3,8$ \\
\hline K. Terbangun & 28,8 & 8,0 & 51,5 & 14,3 & 22,7 & 6,3 \\
\hline Tubuh Air & 2,0 & 0,6 & 2,6 & 0,7 & 0,5 & 0 \\
\hline \multicolumn{7}{|l|}{ Tabel 6 (Lanjutan) } \\
\hline Lainnya & 0,1 & 0 & 0,2 & 0 & 0,1 & 0 \\
\hline Jumlah & 359,5 & 100 & 359,5 & 100 & 0 & 0 \\
\hline
\end{tabular}

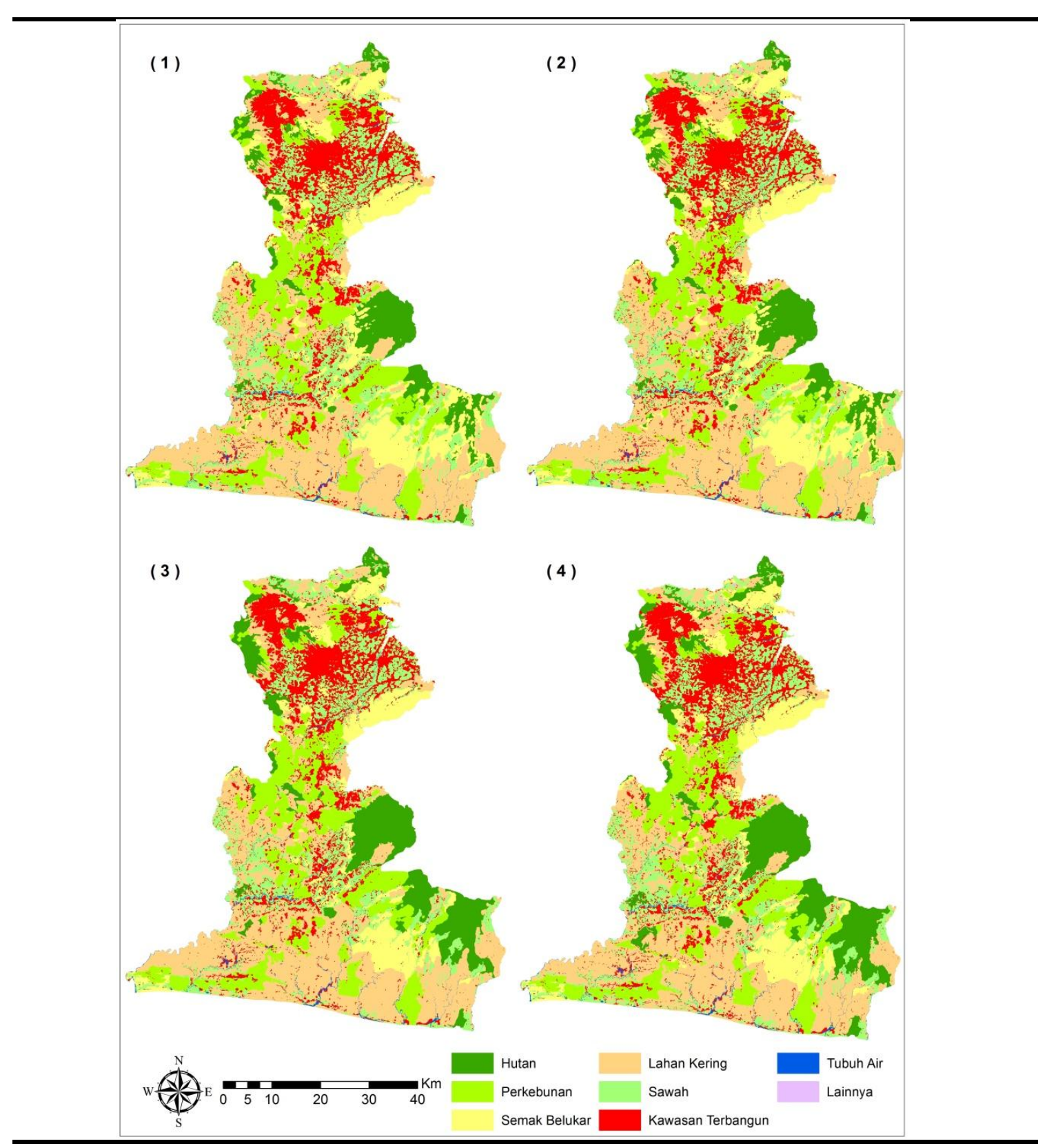

Gambar 4. Peta Prediksi Perubahan Penggunaan Lahan Kabupaten Cianjur Tahun 2025 (1) Tanpa Skenario, (2) Skenario 1, (3) Skenario 2 dan (4) Skenario 3 
Hasil prediksi skenario 2 menujukkan perubahan penggunaan lahan di Kabupaten Cianjur masih cukup dinamis. Persentase hutan, semak belukar dan lahan pertanian mengalami penurunan yang bervariasi dari $2 \%-4 \%$, sedangkan perkebunan sama seperti skenario sebelumnya yaitu mengalami kenaikan sebesar 4,9\%. Hasil evaluasi kesesuaian dengan RTRW menunjukkan Kabupaten Cianjur memiliki kesesuaian penggunaan lahan prediksi dengan RTRW sebesar $40,5 \%$, tidak sesuai sebesar $17,1 \%$ dan penggunaan lahan yang memungkinkan untuk berubah $42,4 \%$.

Tabel 7 Luas dan Perubahan Penggunaan Lahan Kabupaten Cianjur Skenario 3

\begin{tabular}{lcrrrrr}
\hline \multirow{2}{*}{ Penggunaan Lahan } & \multicolumn{3}{c}{ Kabupaten Cianjur } \\
\cline { 2 - 7 } & \multicolumn{2}{c}{2014} & \multicolumn{2}{c}{2025} & \multicolumn{2}{c}{ Perubahan } \\
\cline { 2 - 7 } & 000 ha & $\%$ & 000 ha & $\%$ & 000 ha & $\%$ \\
\hline Hutan & 50,6 & 14,1 & 46,4 & 12,9 & $-4,2$ & $-1,2$ \\
Perkebunan & 42,8 & 11,9 & 60,4 & 16,8 & 17,6 & 4,9 \\
Semak Belukar & 45,1 & 12,5 & 37,1 & 10,3 & $-8,0$ & $-2,2$ \\
Lahan Kering & 121,6 & 33,8 & 102,9 & 28,6 & $-18,8$ & $-5,2$ \\
Sawah & 68,4 & 19,0 & 58,4 & 16,2 & $-10,0$ & $-2,8$ \\
K. Terbangun & 28,8 & 8,0 & 51,6 & 14,4 & 22,8 & 6,5 \\
Tubuh Air & 2,0 & 0,6 & 2,6 & 0,7 & 0,5 & 0 \\
Lainnya & 0,1 & 0 & 0,2 & 0 & 0,1 & 0 \\
\hline Jumlah & 359,5 & 100 & 359,5 & 100 & 0 & 0 \\
\hline
\end{tabular}

Hasil prediksi skenario 3 dengan kebijakan dimana hutan dan semak belukar yang berada di kawasan lindung dipertahankan atau tidak boleh berubah fungsi serta pertanian lahan kering yang juga berada pada kawasan lindung dikembalikan fungsinya menjadi hutan menunjukkan pada Kabupaten Cianjur mengalami peningkatan luasan pada perkebunan dan kawasan terbangun yaitu sebesar 6,5\% dan 4,9\%. Penurunan luas terbesar terjadi pada lahan kering sebesar 5,2\%, sawah 2,8\%, semak belukar 2,2\% dan hutan sebesar $1,2 \%$. Hasil evaluasi kesesuaian dengan RTRW menunjukkan Kabupaten Cianjur memiliki kesesuaian penggunaan lahan prediksi dengan RTRW sebesar $40,1 \%$, tidak sesuai sebesar $16,6 \%$ dan penggunaan lahan yang memungkinkan untuk berubah sebesar $43,3 \%$.

\section{KESIMPULAN}

Perubahan penggunaan lahan yang terjadi di Kabupaten Cianjur dari tahun 2000 hingga 2014 didominasi oleh perubahan hutan menjadi menjadi non-hutan dengan persentase penurunan luasan hutan sebesar 10,3\% serta peningkatan penggunaan lahan perkebunan sebesar 5\% dan semak belukar sebesar 3,9\%. Kawasan terbangun juga mengalami peningkatan sebesar 2,8\%. Hasil prediksi tahun 2025 juga menunjukkan penurunan luasan hutan sebesar $6,4 \%$ sedangkan peningkatan luasan yang sangat tajam tejadi pada penggunaan lahan kawasan terbangun. Persentase kesesuaian penggunaan lahan eksisting terhadap RTRW di Kabupaten Cianjur sebesar 40,8\%, tidak sesuai sebesar $10,4 \%$ dan penggunaan lahan yang memungkinkan untuk berubah $48,8 \%$. Namun hasil prediksi menunjukkan persentase ketidaksesuaian penggunaan lahan terhadap RTRW meningkat tajam yaitu sebesar 20,5\%.Arahan skenario tiga, dimana hutan dan semak belukar yang berada di kawasan lindung dipertahankan atau tidak boleh berubah fungsi serta pertanian lahan kering yang juga berada pada kawasan lindung dikembalikan fungsinya menjadi hutan, dapat mengendalikan perubahan penggunaan lahan dimana nilai ketidaksesuaian yang terjadi Kabupaten Cianjur dapat diturunkan menjadi 16,6\%. 


\section{DAFTAR PUSTAKA}

.[FWI] Forest Watch Indonesia. 2011. Potert Keadaan Hutan Indonesia Periode 2000-2009. Bogor (ID): Forest Watch Indonesia

[BPBD].Badan Penanggulangan Bencana Daerah. 2015. Data Bencana Kabupaten Cianjur. http://bpbdkabcianjur.blogspot.co.id/ [diakses pada Desember 2015].

Arsanjani JK, Helbich M, Kainz W and Boloorani AD. 2013. Integration of Simulate Urban Expansion. Applied Earth Observation and Geoinformation 21: 265-275.

Chen J, Peng G, Chunyang H, Wei L, Masayuki T, Peijun S. 2002. Assessment of the Urban Development Plan of Beijing by Using CA-based Urban Growth Model. International Journal of Photogrametric Engineering and Remote Sensing. 68(10): 1063 - 1073.

Eastman. J. R. 2003. IDRISI Kilimanjaro: Guide to GIS and Image Processing. Massachusetts (US): Clark University.

El-Hallaq MA., Habboub MO. 2015. Using Cellular automata-Markov Analysis and Multi Criteria Evaluation for Predicting the Shape of the Dead Sea. Scienctific Research Publishing 4: 83-95.

Huan Y. Zhengwei H and Xin P. 2010. Wetland Shrink Simulation Using Cellular Automata: A Case Study in Sanjiang. China. Procedia Environmental Science. 2: 225-233

Kumar R, Nandy S, Agarwal R, and Kushwaha SPS. 2014. Forest Cover Dynamics Analysis and Prediction Modelling using Logistic Regression Model. Ecological Indicators45: 444-455.

Manson S. 2005. Land Use in the Southern Yucata in Peninsular Region of Mexico: Scenarios of Population and Institutional Change. Environment and Urban Systems 30: 230-253.

McConnel WJ.2001. Preface in Report and Review of International Workshop of Agent Based Models of Land Use and Land Cover Change. pp:xi-xiv.California (US): LUCC Focus 1 Office.

Nong Y and Du Q. 2011. Urban Growth Pattern Modelling Using Logistic Regression. Geo-spatial Information Science 14(1): 62-67.

Pribadi DO., Shiddiq D., Ermyanila M. 2006. Model Perubahan Tutupan Lahan dan Faktor-Faktor yang Mempengaruhinya. Jurnal Teknologi Lingkungan. 7:35-51.Pusat Pengkajian dan Penerapan Teknologi Lingkungan.

Ramlan A, Solle MS dan Seniarwan. 2015. Dinamika dan Proyeksi Perubahan Penggunaan Lahan di Kawasan Peri-Urban Kota Makassar (Kawasan Mamminasata). Prosiding Pertemuan Ilmiah Tahunan MAPIN XX: 57-67.

Sitorus SRP. 2015. Evaluasi Lahan dan Perencanaan Penggunaan Lahan Landasan Ilmiah Penataan Ruang dan Penggunaan Wilayah. Orasi Ilmiah Guru Besar IPB. Bogor, 12 September 2015. Bogor (ID): PT. Penerbit IPB Press.

Wijaya MS. 2013. Integrasi Model Spasial Cellular Automata dan Regresi Logistik Biner untuk Pemodelan Dinamika Perkembangan Lahan Terbangun. Yogyakarta (ID): Fakultas Geografi Universitas Gadjah Mada. 